\title{
Variation in the structure of the ichthyoplankton community in the lower Paraíba do Sul River
}

\author{
Gabriel E. Teixeira ${ }^{1}$, Andréa Bialetzki², Bruno E. Soares ${ }^{1}$, Guilherme Souza ${ }^{3}$ \\ and Érica P. Caramaschi ${ }^{1}$
}

\begin{abstract}
The Paraíba do Sul River is affected by extensive water collection for supply, organic and industrial pollution, and dams. Nonetheless, the ichthyofauna maintains biodiversity and sustains artisanal fisheries. This study analyzes the composition, abundance and distribution of fish larvae, an important approach to determine the reproductive period and spawning sites. The sampling occurred from August 2011 through February 2013 in five sites at a transect between the banks on the lower reach of the Paraíba do Sul River. A total of 5,412 larvae belonging to 20 taxa was captured. The predominant order was Characiformes. Larvae of Prochilodus spp. and Leporinus spp. were the most abundant; larvae of Brycon insignis, an endangered species, were present. Fewer larvae were collected in the second reproductive cycle during a severe drought. The absence of eggs indicates that the study area is not used for spawning, and highlights the need for studies in the main channel and in the tributaries of the Paraíba do Sul River. Fish larvae need to have access to the marginal lagoons along the lower stretch of the river, an area which is the object of disputes between fishermen and farmers.
\end{abstract}

Key words: Drought, Eggs and larvae, Migratory species, Reproductive period, Spawning area.

O rio Paraíba do Sul é afetado por retirada de água para abastecimento, poluição orgânica e industrial e barramentos, mas mantém a biodiversidade de peixes e sustenta a pesca artesanal. Este estudo apresenta a composição, abundância e distribuição de larvas de peixes, abordagem importante para determinar o período de reprodução e locais de desova. A amostragem ocorreu entre agosto de 2011 e fevereiro de $2013 \mathrm{em}$ cinco pontos de um transecto de $500 \mathrm{~m}$ entre as margens no trecho inferior do rio Paraíba do Sul. Um total de 5.412 larvas de 20 táxons foi capturado. Predominaram Characiformes, sendo que larvas de Prochilodus spp. e Leporinus spp. foram as mais abundantes. Larvas de Brycon insignis, espécie em extinção, foram registradas. Larvas foram menos abundantes no segundo ciclo reprodutivo, coincidindo com o início de uma seca severa na região. A ausência de ovos nas amostras indica que a área estudada não é utilizada para desova e aponta a necessidade de estudos no canal principal a montante e nos afluentes. Ressaltamos a necessidade de acesso das larvas às lagoas marginais no trecho inferior do rio Paraíba do Sul, área objeto de desentendimentos entre pescadores e agricultores.

Palavras-chave: Espécies migradoras, Estiagem, Local de desova, Ovos e larvas, Período reprodutivo.

\section{Introduction}

The Paraíba do Sul River is the largest coastal river in southeastern Brazil (Bizerril, 1999). Because it flows through one of the largest urban-industrial regions, this river is one of the most impacted lotic systems in the country (Araújo, 1996; Bizerril, 1999). The basin, which receives 309.3 million $\mathrm{m}^{3} /$ year of sewage in natura, provides ecological services to nearly 11 million people and more than 8,000 industrial plants
(ANA, 2012), leading to severe environmental problems. Commercial sand extraction along the main channel increases the load of suspended solids and causes erosion and homogenization of the substrate (Pinto et al., 2006a,b).

The Paraíba do Sul River is also impacted by the installation of hydroelectric dams. Five hydroelectric projects are located in the main channel of the river, two of them in the middle-lower stretch. Currently, a sixth hydroelectric dam is in the construction phase (Itaocara

${ }^{1}$ Universidade Federal do Rio de Janeiro, Laboratório de Ecologia de Peixes, Av. Carlos Chagas Filho, Cidade Universitária, 21941590 Rio de Janeiro, RJ, Brazil. (GET) gabrielennes@msn.com (corresponding author), (Dhttps://orcid.org/0000-0001-5198-5653; (BES) soares.e.bruno@gmail.com, Dhttps://orcid.org/0000-0001-5678-0403; (EPC) erica.caramaschi@gmail.com, Dhttps://orcid. org/0000-0002-3371-4996

${ }^{2}$ Universidade Estadual de Maringá, Núcleo de Pesquisas em Limnologia, Ictiologia e Aquicultura, Av. Colombo, 5790, Campus Universitário, 87020-900 Maringá, PR, Brazil. bialetzki@nupelia.uem.br, Đhttps://orcid.org/0000-0002-8048-5049

${ }^{3}$ Universidade Estadual do Norte Fluminense, Av. Alberto Lamego, 2000, Parque Califórnia, 28013-602 Campos dos Goytacazes, RJ, Brazil. guilhermesouza.bio@gmail.com, Dhttps://orcid.org/0000-0002-0834-6415 
Hydroelectric Dam) and a seventh is in the planning phase (Pomba River Hydroelectric Dam). Despite its severely impacted state, the middle-lower stretch harbors numerous families that subsist on artisanal fishing, including a local fishermen's cooperative association, and several endangered species of fishes (Polaz et al., 2011). Several studies have examined the fish communities and the reproductive aspects of fishes in the basin (Mazzoni, Caramaschi 1995; Mazzoni, Caramaschi 1997a,b; Menezes et al., 1998; Araújo et al., 2001; Costa et al., 2005; Teixeira et al., 2005; Araújo et al., 2009; Santos et al., 2013; Lima et al., 2018); still, knowledge of the eggs and larvae of fishes in the basin is lacking.

The reproductive period of fish depends on favorable environmental conditions that maximize offspring survival and development (Agostinho et al., 2004; Winemiller, 2004). The main environmental variables that affect fish reproduction and the structure of the ichthyoplankton community in rivers are photoperiod (Vazzoler et al., 1997), temperature (Reynalte-Tataje et al., 2008), river flow (Agostinho et al., 2004) and resource availability (Vazzoler, 1996). These environmental variables can vary widely during the year and between years, depending upon the macroclimate and regional and local ecological processes (Krabbenhoft et al., 2014).

Knowledge of the spatio-temporal distribution of fish eggs and larvae is helpful in establishing local reproductive parameters and nursery areas (e.g. Baumgartner et al. 2004). Preserved areas for spawning and growth assure the recruitment of juveniles to adult populations, and consequently the diversity and abundance of the ichthyofauna in a hydrographic basin. Therefore, a temporal perspective on the structure of the ichthyoplankton is not only desirable, but mandatory in order to establish efficient management measures for river faunas.

This is the first study of the temporal variation of the structure of the ichthyoplankton in the Paraíba do Sul River. We evaluated the temporal variation in the structure of the ichthyoplankton, both hourly (temporal-stratum) and monthly (seasonal). Our data comprise two reproductive cycles of the fishes in the river, which allowed us to describe variation in the structure of the ichthyoplankton between two years with different environmental conditions. Finally, we comment on the ecological importance of maintaining the ability of fish to access marginal lakes, and on the local political situation related to water management.

\section{Material and Methods}

Study area. The Paraíba do Sul River stretches over 1,080 $\mathrm{km}$, in a $57,000 \mathrm{~km}^{2}$ hydrographic basin (Bizerril, 1999; Hilsdorf, Petrere Jr., 2002). The sampling sites were located $35 \mathrm{~km}$ upstream from the river mouth, near the mouths of three large tributaries (Pomba, Dois Rios and Muriaé) and $185 \mathrm{~km}$ downstream from the Ilha dos Pombos Hydroelectric Dam. Pomba and Muriáe discharge on the left bank of the Paraíba do Sul River, located 110 and $20 \mathrm{~km}$ from the sampling sites, respectively. The Dois Rios River is a right-bank affluent, located $60 \mathrm{~km}$ from the sampling sites.

We sampled in five sites within a $840 \mathrm{~m}$ transect line between the river banks in the lower stretch of the Paraíba do Sul River, near the Unidade de Pesquisa e Extensão AgroAmbiental (UPEA; 21 44'22.0'S and 41 '12'26.2”W) (Fig. 1).

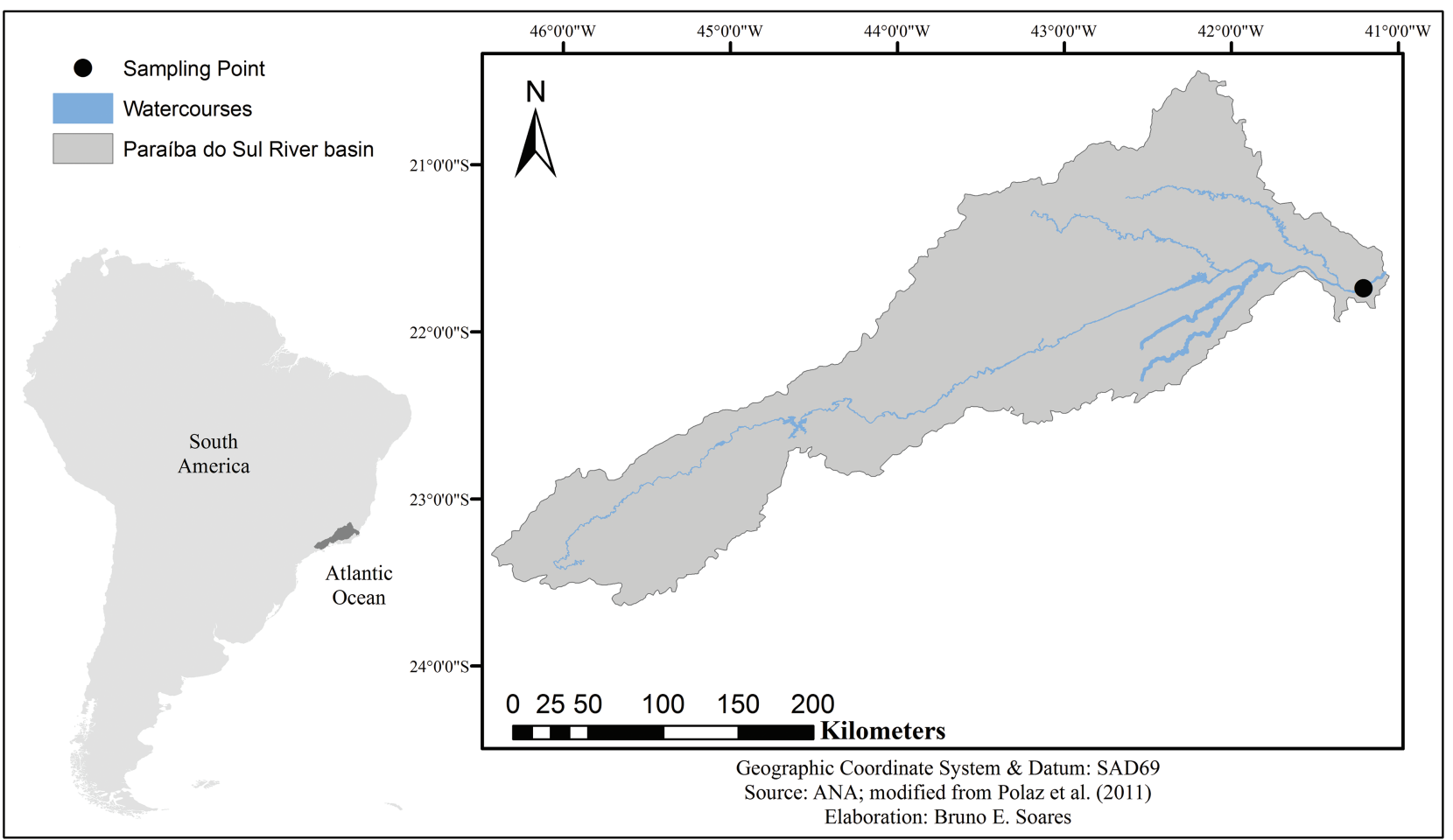

Fig. 1. Sampling area in the Paraíba do Sul River, where sampling was carried out from August 2011 through February 2013. 
The depth ranged from 0.9 to $1.6 \mathrm{~m}$ in the dry season (April through September) and from 1.3 to 5.7 in the rainy months (October through March). The main channel has a mainly sandy bottom and several islands, most of them vegetated. The right bank is located only a few meters from the highway BR-356, and is an area of intense human activity, sparse riparian vegetation and a high volume of garbage. The left bank exhibits some riparian vegetation, but is located nearby sugarcane plantations.

Sampling design. Sampling was carried out monthly in all five sites from August 2011 through February 2013, comprising 19 months. From October through March (rainy season), samples were taken for $72 \mathrm{~h}$ at 6-h intervals. From April through September (dry season), samples were taken for 24 $\mathrm{h}$ at 6-h intervals. Samples were carried out by two conicalcylindrical plankton nets $(500 \mu \mathrm{m})$ tied to metal cables that were set out against the river flow for $10 \mathrm{~min}$. All sampling procedures included one sample on the surface and another at the bottom of the river. Therefore, it summed 400 samples in the dry season and 1,430 samples in the rainy season. A flowmeter was attached in each net to determine the volume of filtered water. Depth (m), dissolved oxygen (mg/L), electrical conductivity $(\mu \mathrm{S} / \mathrm{cm}), \mathrm{pH}$, temperature $\left({ }^{\circ} \mathrm{C}\right)$ and turbidity were obtained simultaneously with the plankton collection. Precipitation and discharge were obtained from the website of the National Water Agency (ANA). Ichthyoplankton samples were fixed in $4 \%$ formaldehyde buffered with calcium carbonate. In the laboratory, ichthyoplankton was sorted and larvae were identified following a regressive development sequence technique (Ahlstrom, Moser, 1976), to the lowest possible taxonomic level, according to Nakatani et al. (2001). Abundance was standardized per volume of 10 $\mathrm{m}^{3}$ filtered water, according to Tanaka (1973) as modified by Nakatani et al. (2001).

Sampled specimens were deposited in the Ichthyology Collection of the Center for Research in Limnology, Ichthyology and Aquaculture (Nupélia) of the State University of Maringá (UEM), Maringá, Paraná (Lots: NUP 21121 to NUP 21135).

Data analysis. Temporal strata variation. The temporal structure of the ichthyoplankton during the diurnal and nocturnal periods was evaluated using the strata (surface and bottom) as co-variable. Samples taken between 08:00 and 16:00 $\mathrm{h}$ were considered diurnal, and samples taken between 20:00 and 04:00 $\mathrm{h}$ were considered nocturnal. We evaluated the differences in the density (dependent variable) of fish larvae between diurnal and nocturnal samples and between strata (independent co-variables), using a two-way Analysis of Variance (ANOVA) with a permutation test. In order to evaluate if the taxonomic composition of ichthyoplankton differed between periods of the day and between strata, we used a Permutation analysis of variance (PERMANOVA) of two factors. PERMANOVA was applied to a matrix of similarity based on the square-root of the density (Bray-
Curtis; dependent variable) and it evaluates if samples within the same group are more similar in composition than samples of different groups.

Seasonal variation. In order to evaluate the existence of abiotic gradients that characterize seasonality, we used a Principal Components Analysis (PCA), using monthly values of the measured abiotic factors (dissolved oxygen, temperature, depth, turbidity, $\mathrm{pH}$ and electrical conductivity). Variables were standardized to zero mean and unit variance prior the analysis. We used the broken-stick model to select axes for ecological explanation. Because the discrepancy in the absolute density between seasons was high, we did not perform a statistical analysis to evaluate differences in absolute density. In order to evaluate if taxonomic composition of the ichthyoplankton differed between hydrologic seasons (rainy vs. dry season), a PERMANOVA was applied to monthly pooled density data for each sampling site. Density was square-rooted in order to calculate Bray-Curtis dissimilarity, and we used 999 iterations. Complementarily, an Analysis of Similarity Percentages (SIMPER) was applied in order to identify which groups were the most important in the observed differences between seasons. Analyses were performed in vegan (Oksanen et al., 2018) and lmPerm (Wheeler, Torchiano, 2016) packages in R 3.4.4. software ( $R$ Core Team 2018).

To approach the interannual variation, we did a graph showing the river flow and the larvae abundance.

\section{Results}

Stages of development. We sampled 5,412 fish larvae, but no fish eggs. Of these, $74 \%$ were in the early stages of development (vitelinic and preflexion stages) and the other $26 \%$ were comprised in the two later stages of development (flexion and postflexion stages).

Taxonomic composition and abundance. Larvae were classified in six orders and 15 families. Most of them were identified as Characiformes $(90.6 \%)$ and Siluriformes (7.5\%); the most abundant taxa were Prochilodus spp. and Leporinus spp. Brycon insignis, a locally endangered species according to the Action Plan for the Conservation of Endangered Aquatic Species from the Paraíba do Sul River (Polaz et al., 2011), and several non-native species were also recorded (Tab. 1).

Temporal strata variation. The daily distribution of the ichthyoplankton showed an interactive effect of the use of the water-column stratum and period of the day ( $p$ $=0.03)$, but variables were not significant separately $(\mathrm{p}>$ $0.7)$. During the day, larvae were more abundant near the river bottom, and at night, larvae were more abundant at the surface. Nevertheless, no significant differences were observed in the composition of fish larvae, neither between water strata $(\mathrm{R}=0.003 ; \mathrm{p}=0.93)$, periods of the day $(\mathrm{R}=$ $0.009 ; \mathrm{p}=0.47)$ or variables interaction $(\mathrm{R}=0.01 ; \mathrm{p}=0.27)$. 
Tab. 1. Absolute and relative densities of larvae sampled during the dry (April 2012 through September 2012) and rainy season (October 2011 through March 2012; and October 2012 through February 2013) in the lower Paraíba do Sul River, Rio de Janeiro. Invasive species are indicated by an asterisk $(*)$.

\begin{tabular}{|c|c|c|c|c|}
\hline \multirow{2}{*}{ Order/Family/Species } & \multicolumn{2}{|c|}{ Dry season } & \multicolumn{2}{|c|}{ Rainy season } \\
\hline & Dens. & $\%$ Dens. & Dens. & $\%$ Dens. \\
\hline \multicolumn{5}{|l|}{ Characiformes } \\
\hline \multicolumn{5}{|l|}{ Anostomidae } \\
\hline Leporinus spp. & 0.80 & 21.35 & 312.26 & 26.23 \\
\hline \multicolumn{5}{|l|}{ Characidae } \\
\hline Unindentified Characidae & 0.27 & 7.18 & 47.67 & 4.00 \\
\hline Astyanax spp. & 0.00 & 0.00 & 29.30 & 2.46 \\
\hline \multicolumn{5}{|l|}{ Bryconidae } \\
\hline Brycon insignis Steindachner, 1877 & 0.00 & 0.00 & 4.51 & 0.38 \\
\hline Salminus brasiliensis (Cuvier, 1816)* & 0.00 & 0.00 & 13.65 & 1.15 \\
\hline \multicolumn{5}{|l|}{ Erythrinidae } \\
\hline Hoplias malabaricus (Bloch, 1794) & 0.00 & 0.00 & 10.48 & 0.884 \\
\hline \multicolumn{5}{|l|}{ Prochilodontidae } \\
\hline Prochilodus spp. & 0.00 & 0.00 & 653.49 & 54.89 \\
\hline \multicolumn{5}{|l|}{ Parodontidae } \\
\hline Apareiodon piracacabae (Eigenmann, 1907)* & 0.00 & 0.00 & 0.58 & 0.05 \\
\hline \multicolumn{5}{|l|}{ Siluriformes } \\
\hline \multicolumn{5}{|l|}{ Pimelodidae } \\
\hline Pimelodus spp. & 0.54 & 14.36 & 73.30 & 6.16 \\
\hline \multicolumn{5}{|l|}{ Heptapteridae } \\
\hline Unindentified Heptapteridae & 0.00 & 0.00 & 5.82 & 0.49 \\
\hline \multicolumn{5}{|l|}{ Loricariidae } \\
\hline Unindentified Loricariidae & 0.00 & 0.00 & 2.25 & 0.19 \\
\hline Hypostomus spp. & 0.00 & 0.00 & 1.28 & 0.11 \\
\hline Rineloricaria spp. & 0.21 & 5.70 & 2.13 & 0.18 \\
\hline \multicolumn{5}{|l|}{ Trichomycteridae } \\
\hline Trichomycterus sp. & 0.21 & 5.70 & 2.44 & 0.20 \\
\hline \multicolumn{5}{|l|}{ Gymnotiformes } \\
\hline \multicolumn{5}{|l|}{ Gymnotidae } \\
\hline Gymnotus cf. carapo Linnaeus, 1758 & 0.00 & 0.00 & 1.11 & 0.09 \\
\hline \multicolumn{5}{|l|}{ Sternopygidae } \\
\hline Eigenmannia virescens (Valenciennes, 1836) & 0.00 & 0.00 & 1.39 & 0.11 \\
\hline \multicolumn{5}{|l|}{ Synbranchiformes } \\
\hline \multicolumn{5}{|l|}{ Synbranchidae } \\
\hline Synbranchus marmoratus Bloch, 1795 & 0.00 & 0.00 & 3.66 & 0.31 \\
\hline \multicolumn{5}{|l|}{ Perciformes } \\
\hline \multicolumn{5}{|l|}{ Cichlidae } \\
\hline Unindentified Cichlidae & 0.48 & 12.76 & 1.49 & 0.12 \\
\hline Cichla spp.* & 0.00 & 0.00 & 0.87 & 0.07 \\
\hline Oreochromis niloticus (Linnaeus, 1758)* & 0.00 & 0.00 & 0.84 & 0.07 \\
\hline \multicolumn{5}{|l|}{ Syngnathiformes } \\
\hline \multicolumn{5}{|l|}{ Syngnathidae } \\
\hline Unindentified Syngnathidae & 0.76 & 20.06 & 4.61 & 0.39 \\
\hline
\end{tabular}

Seasonal variation. The PCA indicated only one axis with statistical significance, which explained $55.3 \%$ of the total variation in abiotic variables among samples (Fig. 2). Variables with the highest correlations with the first axis were dissolved oxygen $(\mathrm{r}=0.46)$, temperature $(\mathrm{r}=-0.48)$ and depth $(\mathrm{r}=-0.47)$. Other variables contributed less to the variation in the first PCA axis: conductivity $(\mathrm{r}=-0.37), \mathrm{pH}(\mathrm{r}=-0.14)$, and turbidity $(\mathrm{r}=-0.43)$. Samples with higher scores on the first axis showed higher dissolved-oxygen concentrations, lower temperatures and shallower depths, mainly samples from the dry season (April through September). Samples from the rainy season (October through March) showed lower values on the first axis, with lower dissolved-oxygen levels, and greater depths and temperature. 


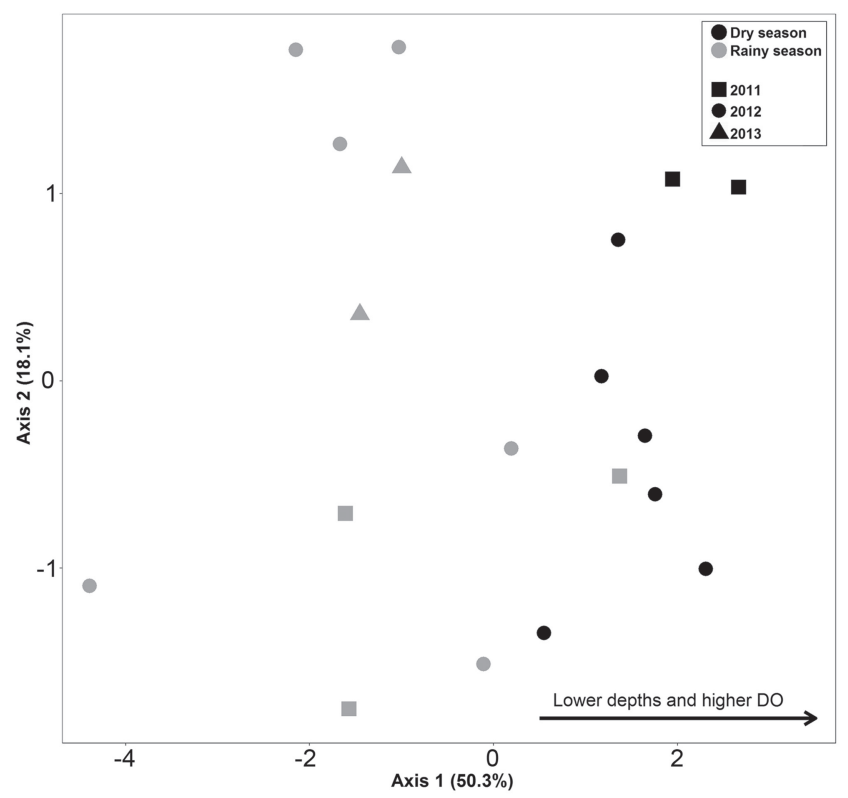

Fig. 2. Principal Components Analysis (PCA) with abiotic variables measured monthly between September 2011 and February 2013 in the lower Paraíba do Sul River. Main correlations of abiotic variables and selected axis are highlighted.

Ninety-nine percent of the fish larvae were caught in the rainy season (from October through March). The ichthyoplankton composition also differed significantly between hydrological seasons $\left(\mathrm{R}^{2}=0.11 ; \mathrm{p}=0.001\right)$.
Differences in composition were mainly explained by lower density of some species in the dry season (Tab. 2).

Tab. 2. Log-transformed values of mean abundance $(A b)$ in the dry and rainy seasons, of migratory species sampled in the lower Paraíba do Sul River (RJ) and the species contribution (\%) to the overall dissimilarity between seasons, assessed by SIMPER analysis.

\begin{tabular}{lccc}
\hline \multicolumn{1}{c}{ Taxa } & $\begin{array}{c}\text { Mean } \mathrm{Ab} . \\
\text { Dry season }\end{array}$ & $\begin{array}{c}\text { Mean } \mathrm{Ab} . \\
\text { Rainy season }\end{array}$ & Contribution \% \\
\hline Leporinus spp. & 0.01 & 1.82 & 30.72 \\
Pimelodus spp. & 0.03 & 0.78 & 10.77 \\
Prochilodus spp. & 0.00 & 1.41 & 9.56 \\
Salminus brasiliensis & 0.00 & 0.28 & 6.70 \\
\hline
\end{tabular}

Interannual variation. The flow of the Paraíba do Sul River differed between the two reproductive periods sampled (Fig. 3), as in the first rainy season (2012) the peak river flow reached almost $2,500 \mathrm{~m}^{3} / \mathrm{s}$. In the rainy season of 2013 , the anticipated peak river flow was only $1,000 \mathrm{~m}^{3} / \mathrm{s}$.

In the first reproductive cycle, from October 2011 through March 2012, higher richness ( $\mathrm{S}=24$ ) was observed, whereas in the second cycle, from October 2012 through February 2013, only 12 species were recorded. The number of individuals was also higher in the first reproductive cycle, comprising 4,184 larvae (83\%), than in the second one (813 larvae). Only four taxa were caught in high numbers in the second cycle: Hoplias malabaricus (Bloch, 1794), Heptapteridae, Cichlidae, and unidentified Syngnathidae (Tab. 3).

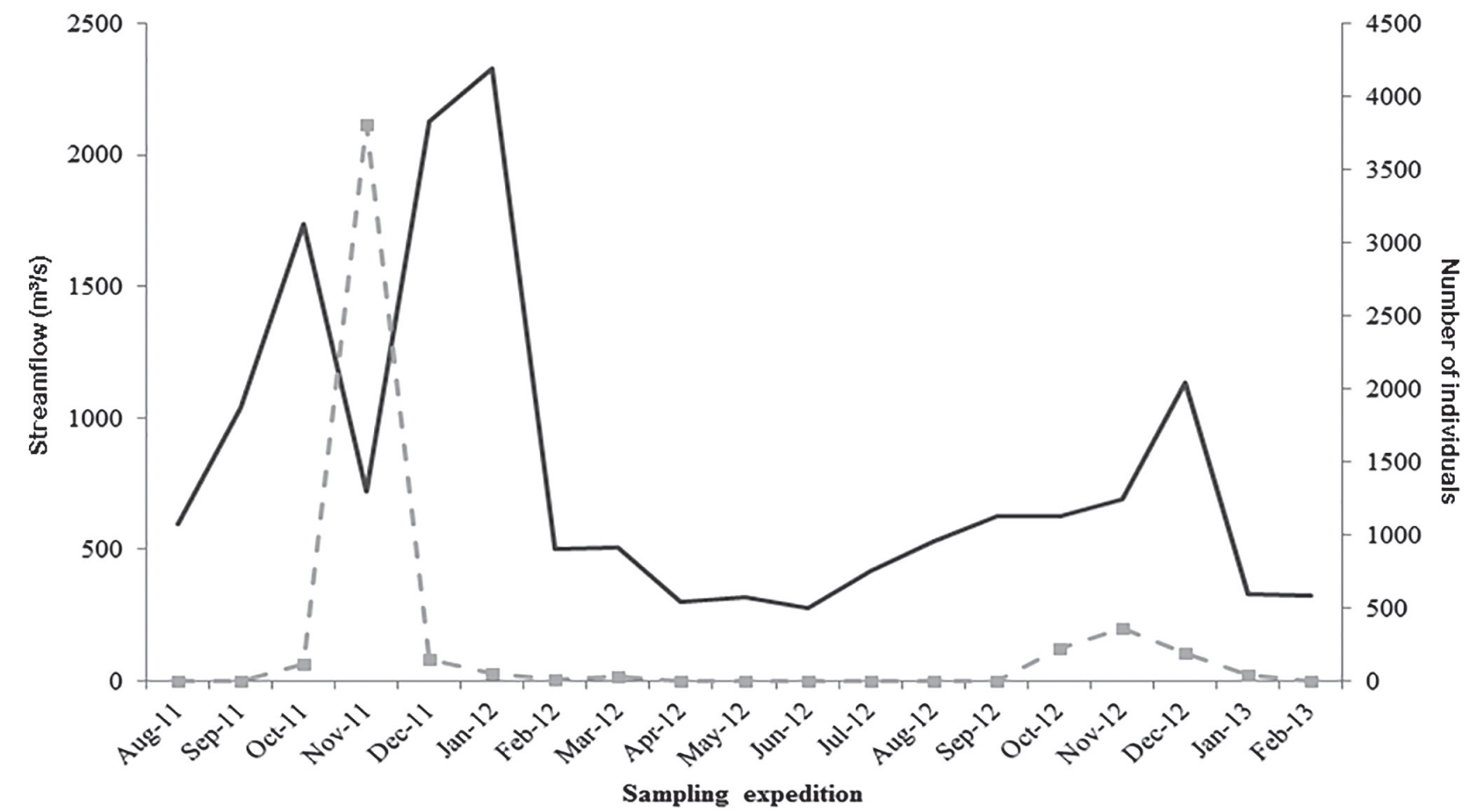

Fig. 3. Variation in the mean monthly river flow (solid line) and number of larvae (dashed line) of the Paraíba do Sul River near Campos dos Goytacazes municipality (RJ) during two rainy seasons (October to March), with same effort. During the dry season (April to September), the effort was minor. 
Tab. 3. Abundance of fish larvae per taxon during two reproductive cycles in the lower Paraíba do Sul River, Rio de Janeiro. The total abundances of larvae in the first and second reproductive periods of fishes in the Paraíba do Sul River are also shown.

\begin{tabular}{|c|c|c|c|c|c|c|c|c|c|c|c|c|c|}
\hline Taxa & Oct $/ 11$ & Nov/11 & Dec/11 & $\mathrm{Jan} / 12$ & $\mathrm{Feb} / 12$ & Mar/12 & Total $1^{\text {sto }}$ & Oct $/ 12$ & Nov/12 & $\mathrm{Dec} / 12$ & $\mathrm{Jan} / 13$ & $\mathrm{Feb} / 13$ & $\begin{array}{c}\text { Total } \\
2^{\text {nd }}\end{array}$ \\
\hline Leporinus spp. & 39 & 852 & 84 & 17 & 2 & 29 & 1023 & 174 & 183 & 77 & 15 & 0 & 449 \\
\hline Astyanax spp. & 28 & 71 & 5 & 0 & 0 & 0 & 104 & 7 & 40 & 4 & 0 & 0 & 51 \\
\hline Salminus brasiliensis & 5 & 29 & 5 & 4 & 0 & 0 & 43 & 0 & 0 & 0 & 23 & 0 & 23 \\
\hline Hoplias malabaricus & 3 & 11 & 1 & 1 & 0 & 0 & 16 & 2 & 23 & 10 & 0 & 0 & 35 \\
\hline Apareiodon piracicabae & 0 & 0 & 0 & 0 & 0 & 2 & 2 & 0 & 0 & 0 & 0 & 0 & 0 \\
\hline Pimelodus spp. & 18 & 156 & 23 & 7 & 0 & 1 & 205 & 0 & 29 & 69 & 4 & 0 & 102 \\
\hline Heptapteridae & 12 & 19 & 3 & 6 & 0 & 0 & 40 & 0 & 19 & 2 & 0 & 0 & 21 \\
\hline Loricariidae & 0 & 1 & 1 & 7 & 0 & 0 & 9 & 0 & 0 & 0 & 0 & 0 & 0 \\
\hline Hypostomus spp. & 1 & 0 & 3 & 1 & 1 & 0 & 6 & 0 & 0 & 1 & 0 & 0 & 1 \\
\hline Synbranchus marmoratus & 0 & 7 & 2 & 3 & 0 & 0 & 12 & 0 & 3 & 0 & 0 & 0 & 3 \\
\hline Cichlidae & 2 & 5 & 0 & 2 & 3 & 0 & 12 & 0 & 9 & 11 & 0 & 0 & 20 \\
\hline Cichla sp. & 0 & 0 & 0 & 0 & 0 & 3 & 3 & 0 & 0 & 0 & 0 & 0 & 0 \\
\hline Oreochromis niloticus & 1 & 0 & 1 & 0 & 0 & 1 & 3 & 0 & 0 & 0 & 0 & 0 & 0 \\
\hline Syngnathidae & 2 & 1 & 0 & 0 & 2 & 0 & 5 & 8 & 7 & 3 & 0 & 0 & 18 \\
\hline Total & 117 & 3814 & 147 & 58 & 10 & 38 & 4184 & 220 & 358 & 193 & 42 & 0 & 813 \\
\hline
\end{tabular}

\section{Discussion}

Large numbers of fish larvae were caught in the lower Paraíba do Sul River, comprising a large set of ecologically and economically important species. The sampling area showed to be an important corridor to drifting larvae in early stage of development (74\%), but not to eggs. The absence of fish eggs may be explained by the low efficiency of drift nets in sampling non-pelagic eggs that adhere to the marginal vegetation, rocks and nests along the riverbanks. This local of the Paraíba do Sul River is not a spawning area of migratory fish species but probably they may spawn nearby upper stream or in tributaries. This hypothesis is supported by the short time between fertilization and larval eclosion of the species in the river, which ranges from 13 hours in Pimelodus maculatus Lacépède, 1803 to 24 hours in Prochilodus vimboides Kner, 1859 (Nakatani et al., 2001; Buzollo, 2011; Souza et al., 2016). Advanced larvae (flexion and postflexion stages) were less abundant, but their presence suggests proximity to downstream nursery areas.

Indeed the sampling area is not far from the river mouth at sea and it is known that migratory fish larvae need to access marginal lakes in the downstream floodplain to complete their development (e.g. Pompeu, Godinho, 2003). Higher densities of larvae near the water surface during the night and near the bottom during the day suggest vertical migration. Nocturnal vertical migration of fish larvae is widely recorded in both tropical (Baumgartner et al., 1997; Araújo-Lima et al., 2001; Bialetzki et al., 2004) and temperate rivers (Corbet, Powles, 1986; Gadomski, Barfoot, 1998). However, the abundance and the composition of ichthyoplankton in our sampled site in Paraíba do Sul River did not differ between periods of the day and night or in the use of the water column (strata). Probably, the shallow depth inhibited the expected pattern that denser larvae would drift along the river bottom, while less dense larvae would drift near the water surface, generating a spatially structured ichthyoplankton, as occurs, for example, in the deeper Negro River in the Amazon Basin (Oliveira, Ferreira, 2008).

The ichthyoplankton showed a pronounced seasonality, characterized by higher densities in the rainy season; a drier rainy season during 2013 exhibited very lower densities. Each species has specific requirements for reproduction and spawning, and successful recruitment of larvae depends on favorable environmental conditions (Urho, 1999). Here, a high concentration of fish larvae occurred during the rainy season, from October to March. In November 2011, an increase in the river level ( 1.5 to $5 \mathrm{~m}$ ) and in the temperature coincided with a massive capture of fish larvae. These characteristics, together with the photoperiod, are important triggers for the start of the reproductive period of many fish species (Vazzoler, 1996; Vazzoler et al., 1997). The increased density of larvae during the rainy season indicates the main reproductive months for fish in the Paraíba do Sul River. 
The ichthyoplankton of the Paraíba do Sul River is composed mainly of Characiformes and Siluriformes, which are common orders in Neotropical rivers (LoweMcConnell, 1987). Ecologically important species comprised both the endangered species $B$. insignis and non-native species. The record of $B$. insignis larvae is good news because indicates that the species is reproducing and that its spawning areas are near the sampling site, since the period to larval eclosion, in captivity, is about 18 hours (Souza, 2004). Nevertheless, it is possible that these larvae are spawned by the adults of $B$. insignis released in the Itaocara region by the Projeto Piabanha for repopulation (Caneppele et al., 2018). The presence of these larvae in the lower Paraíba do Sul River is a positive sign either way, because it may indicate the resilience of the wild population of $B$. insignis and/or demonstrate the success of the fish stocking effort. Presence of larvae of the migratory Salminus brasiliensis, Pimelodus spp. and of the nonmigratory Cichla spp. and Oreochromis niloticus inform spawning area of these introduced species in Paraíba do Sul basin (e.g. Moraes et al., 2017). Our findings about larvae of Apareiodon piracicabae extends the known area of occurrence and reproduction of this non-native species, now widespread in the basin (Moraes et al., 2017; Salgado et al., 2017; Bartolette et al., 2018).

The species of genus Prochilodus and Leporinus are economically important to local artisanal fishery. The species with the highest density were Prochilodus spp. Two species of Prochilodus occur in the river: P. lineatus (Valenciennes, 1837) and P. vimboides. Larvae of Prochilodus occurred mainly in the yolk-sac and preflexion stages, which do not allow identification to species level. Nevertheless, $P$. vimboides is locally endangered, and its occurrence is less probable. Mature individuals of $P$. lineatus $(=P$. $s c r o f a$ ) reproducing between November and January were previously caught in tributaries of the river (Dois Rios, Pomba and Muriaé rivers), which may supply fish larvae to the main channel (Caramaschi et al., 1991; Lima et al., 2018). Prochilodus lineatus showed similar reproductive peaks in other basins (Baumgartner et al., 2008; HermesSilva et al., 2009; Reynalte-Tataje et al., 2012).

The presence of larvae of Leporinus spp., Characidae and Pimelodus spp. in September shows that some species begin their reproductive period before the rainy season. The spawning, which lasts for several months, indicates that these groups are less susceptible to specific environmental conditions. These groups were caught during most of the rainy season. It is essential that further research identify these taxa to species level, though. Larvae of some genera are difficult to identify to species level, and therefore it is possible that the continuous record of larvae of the same genus results from temporal segregation in the reproduction of species of the same genus. Larvae of Leporinus and Pimelodus occur over a wide time span in the Ivinhema River, Paraná River basin, and correspond to two and four morphotypes, respectively (Reynalte-Tataje et al., 2012). In the Paraíba do Sul River, three species of Leporinus have been recorded: Leporinus conirostris Steindachner (now Megaleporinus conirostris (Steindachner, 1875)); L. copelandii Steindachner, 1875 and L. steindachneri Eigenmann, 1907. Therefore, it is possible that the high frequency of occurrence of larvae of Leporinus may result from short-term reproductive activities of each of the three species.

As described above, the structure of the ichthyoplankton is strongly related to environmental conditions. There was a pronounced hydrological deficit in Southern Brazil between July 2012 and June 2013, which is the driest period observed by the satellites GRACE TWSA of NASA (U.S. National Aeronautics and Space Administration) in the last 35 years, even more severe than the dry season in the beginning of 2000 (Getirana, 2016). These atypical environmental conditions produced by the hydrological deficit seem to have affected the structure of the ichthyoplankton, reducing densities and changing the species composition. This variation indicates the importance of sampling larvae over longer time periods, rather than over a single reproductive cycle. Here, in the second year the lower richness and abundance of larvae were notable, with few exceptions, such as the non-migratory H. malabaricus, Heptapteridae, Cichlidae and Syngnathidae, which despite their low densities, were more abundant when the river was lower.

The Paraíba do Sul River has a long history of human-induced disturbances (Carvalho, Salomão, 2018), including recent chemical contaminations (Oliveira, 2018), modifying environmental characteristics and eroding its biodiversity and ecosystem functions. Even after a series of disturbances, the richness and abundance of fish larvae demonstrated here is a strong indicator of the resilience of the local ichthyofauna. The river tributaries may have an essential role in maintaining the resilience of the river ecosystem, by supplying larvae and adults. Therefore, it is crucial to assess the relative role of these tributaries for the larvae drifting into the main channel.

Finally, the study stretch proved not to be a spawning area, but a dispersal route for drifting fish larvae of different developmental stages, highlighting the importance of protecting and fostering the access of larvae to the marginal lakes in the Paraíba do Sul system. These lakes are numerous downstream from the study site, which is only $35 \mathrm{~km}$ upstream from the river outflow in the Atlantic Ocean. The use of hydraulic gates to manage the water flow between marginal lakes and the Paraíba do Sul main channel has been causing conflicts between producers and artisanal fishermen (Carneiro, 2004). In addition to the loss of fishing in the marginal lakes claimed by fishermen, the drifting larvae cannot access these lakes and must complete their development in the unfavorable conditions along the riverbanks or are lost to the estuary.

We suggest that monitoring of the ichthyoplankton in the lower Paraíba do Sul River can be successfully concentrated in the rainy season. The seasonal and interannual variations in environmental conditions affect the structure of the 
ichthyoplankton and consequently the recruitment of fish to adult populations. Therefore, the rainfall regime is a strong factor controlling fish reproductive events in the river, and therefore even more intense dry periods caused by climate change are a matter of concern for conservation and maintaining fish stocks (Nazareno, Laurance, 2015).

\section{Acknowledgments}

We thank Vicente de Paulo Santos Oliveira, head of the Núcleo Unidade de Pesquisa e Extensão Agro-Ambiental do Instituto Federal Fluminense (UPEA-IFF), for the complete logistical support during the sampling. We thank to CAPES and FAPERJ (E-26/200.758/2019) for PhD grants provided to GET and BES, respectively. We also are grateful to members of the Laboratório de Ecologia de Peixes for helping in the fieldwork and data analysis, and to Fernanda Estrella for designing the map. We thank Janet Reid for the English review.

\section{References}

Agência Nacional de Águas (ANA). Conjuntura dos recursos hídricos no Brasil: informe 2012 [Internet]. Brasília: Agência Nacional de Águas; 2012. Available from: http://www3.snirh. gov.br/portal/snirh/centrais-de-conteudos/conjuntura-dosrecursos-hidricos/conj2012_inf.pdf

Agostinho AA, Bini LM, Gomes LC, Júlio Júnior HF, Pavanelli CS, Agostinho CS. Fish assemblages. In: Thomaz SM, Agostinho AA, Hahn NS, editors. The upper Paraná River and its floodplain: physical aspects, ecology and conservation. Leiden: Backhuys Publishers; 2004. p.223-46.

Araújo FG. Composição e estrutura da comunidade de peixes do médio e baixo rio Paraíba do Sul, RJ. Rev Bras Biol. 1996; 56(1):111-26.

Araújo FG, Fichberg I, Pinto BCT, Peixoto MG. Variações espaciais na assembleia de peixes no rio Paraíba do Sul (Barra Mansa, Barra do Piraí), Rio de Janeiro, Brasil. Rev Bras Biol. 2001; 18(2):483-92.

Araújo FG, Pinto BCT, Teixeira TP. Longitudinal patterns of fish assemblages in a large tropical river in southeastern Brazil: evaluating environmental influences and some concepts in river ecology. Hydrobiologia. 2009; 618:89-107. http://dx.doi. org/10.1007/s10750-008-9551-5

Araújo-Lima CARM, Silva VV, Petry P, Oliveira EC, Moura SML. Diel variation of larval fish abundance in the Amazon and rio Negro. Rev Bras Biol. 2001; 61(3):357-62. http://dx.doi. org/10.1590/S1519-69842001000300003

Bartolette R, Lima D, Pacheco AG, Carvalho A, Peçanha ELS, Souza G, Caramaschi EP. Composição e riqueza de espécies da ictiofauna no Domínio das Ilhas Fluviais da bacia do rio Paraíba do Sul. In: Berriel TCS, Caramaschi EP, Polaz CNM, editors. Monitoramento da fauna aquática: funções ecossistêmicas do Domínio das Ilhas Fluviais do rio Paraíba do Sul. Itaocara, RJ: Projeto Piabanha; 2018. p.101-30. https://ebookprojetopiaban. wixsite.com/ebook.
Baumgartner G, Nakatani K, Cavicchioli M, Baumgartner MST. Some aspects of the ecology of fish larvae in the floodplain of the high Paraná River, Brazil. Rev Bras Biol. 1997; 14(3):55163. http://dx.doi.org/10.1590/S0101-81751997000300005

Baumgartner G, Nakatani K, Gomes LC, Bialetzki A, Sanches PV. Identification of spawning sites and natural nurseries of fishes in the upper Paraná River, Brazil. Environ Biol Fish. 2004; 71(2):115-25. https://dx.doi.org/10.1007/s10641-004-0098-z

Baumgartner G, Nakatani K, Gomes LC, Bialetzki A, Sanches PV, Makrakis MC. Fish larvae from the upper Paraná River: do abiotic factors affect larval density? Neotrop Ichthyol. 2008; 6(4):551-58. http://dx.doi.org/10.1590/S167962252008000400002

Bialetzki A, Nakatani K, Sanches PV, Baumgartner G. Eggs and larvae of the "curvina" Plagioscion squamosissimus (Heckel, 1840) (Osteichthyes, Sciaenidae) in the Baía River, Mato Grosso do Sul State, Brazil. J Plankton Res. 2004; 26(11):132736. https://dx.doi.org/10.1093/plankt/fbh123

Bizerril CRSF. A ictiofauna da bacia do rio Paraíba do Sul: biodiversidade e padrões biogeográficos. Braz Arch Biol Technol. 1999; 42(2):233-50. http://dx.doi.org/10.1590/ S1516-89131999000200014

Buzollo HR, Veríssimo-Silveira IR, Oliveira-Almeida IR, Alexandre JS, Okuda HT, Ninhaus-Silveira A. Structural analysis of the Pimelodus maculatus (Lacépède, 1803) embryogenesis (Siluriformes: Pimelodidae). Neotrop Ichthyol. 2011; 9(3):601-16. http://dx.doi.org/10.1590/S167962252011000300013

Caneppele D, Hilsdorf AWS, Polaz CNM, Souza G. Estratégias para a conservação de peixes ameaçados de extinção na bacia do rio Paraíba do Sul: motivações históricas e atuais para a recuperação dos recursos genéticos. In: Berriel TCS, Caramaschi EP, Polaz CNM, editors. Monitoramento da fauna aquática: funções ecossistêmicas do Domínio das Ilhas Fluviais do Rio Paraíba do Sul. Itaocara, RJ: Projeto Piabanha; 2018. p.181-214. https://ebookprojetopiaban.wixsite.com/ebook

Caramaschi EP, Aranha JMR, Thiago HS, Moraes JR, Halboth DA, Menezes MS, Vianna M, Gomes JHC, Francischini D. Levantamento da ictiofauna do rio Paraíba do Sul e ciclo reprodutivo das principais espécies, no trecho compreendido entre Três Rios e Campos. Rio de Janeiro: Fundação José Bonifácio/UFRJ; Engevix/Furnas Centrais Elétricas S. A.; 1991. vol II. Aspectos reprodutivos da ictiofauna. Relatório Técnico.

Carneiro PRF. Água e conflito na Baixada dos Goytacazes. REGA. 2004; 1(2):87-100.

Carvalho CEV, Salomão MSMB. Histórico, características e cenário ambiental da bacia de drenagem In: Berriel TCS, Caramaschi EP, Polaz CNM, editors. Monitoramento da fauna aquática: funções ecossistêmicas do Domínio das Ilhas Fluviais do Rio Paraíba do Sul. Itaocara, RJ: Projeto Piabanha; 2018. p.39-59. https://ebookprojetopiaban.wixsite.com/ebook

Corbert BW, Powles PM. Spawning and larva drift of sympatric walleyes and white suckers in an Ontario stream. Trans Am Fish Soc. 1986; 115(1):41-46. https://dx.doi.org/10.1577/15488659(1986)115<41:SALDOS $>2.0 . \mathrm{CO} ; 2$ 
Costa APR, Andrade DR, Vidal Jr. MV, Souza G. Indicadores quantitativos da biologia reprodutiva de fêmeas de piauvermelho no Rio Paraíba do Sul. Pesq Agropec Bras. 2005; 40(8):789-95. http://dx.doi.org/10.1590/S0100204X2005000800009

Gadomski DM, Barfoot CA. Diel and distributional abundance patterns of fish embryos and larvae in the lower Columbia and Deschutes rivers. Environ Biol Fish. 1998; 51(4):353-68. https://dx.doi.org/10.1023/A:1007485015830

Getirana A. Extreme water deficit in Brazil detected from space. J Hydrometeorol. 2016; 17:591-99. https://dx.doi.org/10.1175/ JHM-D-15-0096

Hermes-Silva S, Reynalte-Tataje D, Zaniboni Filho E. Spatial and temporal distribution of ichthyoplankton in the upper Uruguay River, Brazil. Braz Arch Biol Technol. 2009; 52(4):933-44. http://dx.doi.org/10.1590/S1516-89132009000400017

Hilsdorf AWS, Petrere Junior M. Conservação de peixes na bacia do rio Paraíba do Sul. Ciência Hoje. 2002; 30(180):62-65.

Krabbenhoft TJ, Platania SP, Turner TF. Interannual variation in reproductive phenology in a riverine fish assemblage: implications for predicting the effects of climate change and altered flow regimes. Freshwater Biol. 2014; 59(8):1744-54. https://dx.doi.org/10.1111/fwb.12379

Lima D, Teixeira GE, Paula MO, Santos AP, Caramaschi EP. Atividade reprodutiva das principais espécies de peixes do Domínio das Ilhas Fluviais do Rio Paraíba do Sul. In: Berriel TCS, Caramaschi EP, Polaz CNM, editors. Monitoramento da fauna aquática: funções ecossistêmicas do Domínio das Ilhas Fluviais do Rio Paraíba do Sul. Itaocara, RJ: Projeto Piabanha; 2018. p.309-30. https://ebookprojetopiaban.wixsite.com/ebook

Lowe-McConnell RH. Ecological studies in tropical fish communities. Cambridge: Cambridge University Press; 1987.

Mazzoni R, Caramaschi EP. Size, structure, sex ratio and onset of sexual maturity of two species of Hypostomus. J Fish Biol. 1995; 47(5):841-49. https://dx.doi.org/10.1111/j.1095-8649.1995. tb06006.x

Mazzoni R, Caramaschi EP. Observations on the reproductive biology of female Hypostomus luetkeni (Lacépède, 1803). Ecol Freshwat Fish. 1997a; 6(1):53-56. http://dx.doir. org/10.1111/j.1600-0633.1997.tb00143.x

Mazzoni R, Caramaschi EP. Spawning season, ovarian development and fecundity of Hypostomus affinis (Osteichthyes, Loricariidae). Rev Bras Biol. 1997b; 57(3):455-62.

Menezes MS, Aranha JMR, Caramaschi EP. Ocorrência e aspectos da biologia reprodutiva Harttia loricariformis (Loricariinae) no trecho inferior do rio Paraíba do Sul (Rio de Janeiro, Brasil). Acta Biol Par. 1998; 27(1-4):15-26. http://dx.doi.org/10.5380/ abpr.v27i0.663

Moraes MB, Polaz CNM, Caramaschi EP, Junior SS, Souza G, Carvalho FL. Espécies exóticas e alóctones da bacia do rio Paraíba do Sul: implicações para a conservação. Biodiversidade Brasileira. 2017; 7(1):34-54.

Nakatani K, Agostinho AA, Baumgartner G, Bialetzki A, Sanchez PV, Makrakis MC, Pavanelli CS. Ovos e larvas de peixes de água doce: Desenvolvimento e manual de identificação. Maringá: EDUEM; 2001.
Nazareno AG, Laurance WF. Brazil's drought: beware deforestation. Science. 2015; 347(6229):1457. http://dx.doi. org/10.1126/science.347.6229.1427-a

Oksanen J, Blanchet FG, Friendly M, Kindt R, Legendre P, McGlinn D, Minchin PR, O'Hara RB, Simpson GL, Solymons P, Stevens MHH, Szoecs E, Wagener H. Vegan. Community Ecology Package: R package version 3.4.4. [Internet]. 2018. Available from: https://cran.r-project.org/ web/packages/vegan/index.html

Oliveira EC, Ferreira EJG. Spawning areas, dispersion and microhabitats of fish larvae in the Anavilhanas Ecological Station, rio Negro, Amazonas State, Brazil. Neotrop Ichthyol. 2008; 6(4):559-66. http://dx.doi.org/10.1590/ S1679-62252008000400003

Oliveira LFD. Domínio das Ilhas Fluviais do rio Paraíba do Sul: o que é e por que o consideramos tão importante. In: Berriel TCS, Caramaschi EP, Polaz CNM, editors. Monitoramento da fauna aquática: funções ecossistêmicas do Domínio das Ilhas Fluviais do rio Paraíba do Sul. Itaocara, RJ: Projeto Piabanha; 2018. p.15-38. https://ebookprojetopiaban. wixsite.com/ebook.

Pinto BCT, Araújo FG, Hughes RM. Effects of landscape and riparian condition on a fish index of biotic integrity in a large southeastern Brazil river. Hydrobiologia. 2006a; 556(1):6983. https://dx.doi.org/10.1007/s10750-005-9009-y

Pinto BCT, Peixoto MG, Araújo, FG. Effects of the proximity from an industrial plant on fish assemblages in the rio Paraíba do Sul, southeastern Brazil. Neotrop Ichthyol. 2006b; 4(2):269-78. http://dx.doi.org/10.1590/S167962252006000200013

Polaz CNM, Bataus YS, Desbiez A, Reis ML. Plano de ação nacional para a conservação das espécies aquáticas ameaçadas de extinção da bacia do rio Paraíba do Sul. Brasília, DF: MMA/ICMBio; 2011.

Pompeu PS, Godinho HP. Ictiofauna de três lagoas marginais do médio São Francisco. In: Águas, peixes e pescadores do São Francisco das Minas Gerais. Belo Horizonte: PUC Minas, 2003. p.167-81.

R Core Team. R: a language and environment for statistical computing [Internet]. Vienna: R Foundation for Statistical Computing; 2018. Available from: https://www.rproject.org/

Reynalte-Tataje DA, Hermes-Silva PA, Bialetzki A, Zaniboni Filho E. Locais de crescimento de larvas de peixes na região do alto rio Uruguai (Brasil). In: Zaniboni Filho E, Nuner APO, editors. Reservatório de Itá: Estudos ambientais, desenvolvimento de tecnologia e conservação da ictiofauna. Florianópolis: Editora da UFSC; 2008. p.159-93.

Reynalte-Tataje DA, Agostinho AA, Bialetzki A, Hermes-Silva S, Fernandes R, Zaniboni Filho E. Spatial and temporal variation of the ichthyoplankton in a subtropical river in Brazil. Environ Biol Fish. 2012; 94(2):403-19. http:// dx.doi.org/10.1007/s10641-011-9955-3)

Salgado FLK, Terra BDF, Geysa SC, Araújo FG. First record of the family Parodontidae (Characiformes) from the Paraíba do Sul river basin, southeastern Brazil. Check List. 2017; 13(6):1091-95. https://dx.doi.org/10.15560/13.6.1091 
Santos ABI, Albieri RJ, Araujo FG. Influences of dams with different levels of river connectivity on the fish community structure along a tropical river in Southeastern Brazil. J Appl Ichthyol. 2013; 29(1):163-71. https://dx.doi.org/10.1111/jai.12027

Souza G. Reprodução induzida, ontogenia inicial, etologia larval e alevinagem da piabanha (Brycon insignis, Steindachner, 1877). [Master Dissertation]. Campos dos Goytacazes, RJ: Universidade Estadual do Norte Fluminense; 2004.

Souza G, Melo E, Caramaschi E, Andrade D, Monteiro L. Early development and allometric growth patterns of the grumatã (Prochilodus vimboides Kner, 1859). Zygote. 2016; 24(3):428-41.

Tanaka S. 1973. Stock assessment by means of ichthyoplankton surveys. FAO Fisheries and Aquaculture (technical paper). 122:33-51.

Teixeira TP, Pinto BCT, Terra BFE, Estiliano O, Gracia D, Araújo FG. Diversidade das assembleias de peixes nas quatro unidades geográficas do rio Paraíba do Sul. Iheringia Sér Zool. 2005; 95(4):347-57. http://dx.doi.org/10.1590/S007347212005000400002

Urho L. Relationship between dispersal of larvae and nursery areas in the Baltic Sea. J Mar Sci. 1999; 56(Suppl):114-21. http:// dx.doi.org/10.1006/jmsc.1999.0634
Vazzoler AEAM. Biologia da reprodução de peixes teleósteos: teoria e prática. Maringá: EDUEM; 1996.

Vazzoler AEAM, Lizama MAP, Inada P. Influências ambientais sobre a sazonalidade reprodutiva. In: Vazzoler, AEAM, Agostinho AA, Hahn NS, editors. A planície de inundação do alto rio Paraná: aspectos físicos, biológicos e socioeconômicos. Maringá: EDUEM; 1997. p.267-80.

Wheeler B, Torchiano M. ImPerm: Permutation tests for linear models. R package version 2.1.0; 2016. Available from: https:// CRAN.R-project.org/package $=1 \mathrm{mPerm}$.

Winemiller KO, Jepsen DB. Migratory Neotropical fish subsidize food webs of oligotrophic blackwater rivers. In: Polis GA, Power ME, Huxel GR, editors. Food webs at the landscape level. Chicago: University of Chicago Press; 2004. p.15-32.

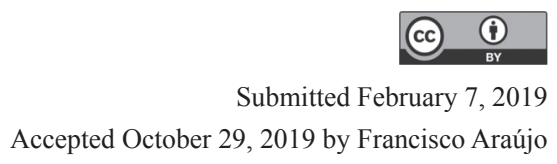

Submitted February 7, 2019

Accepted October 29, 2019 by Francisco Araújo 